\title{
Mary Hayden and Jeff Thomson (Eds.), International Schools: current issues and future prospects, Oxford: Symposium books, 2016; 240 pp.: ISBN 978-1-873927- 92-2
}

Reviewed by Mirko MrČElA ${ }^{1}$

As repeatedly emphasized in this collection of chapters, international schools are currently experiencing unprecedented growth, and the contributors relate in different ways to aspects of international schools. Although the concept of an international school seems to elude precise definition, the authors agree that the majority of international schools had a similar purpose: to cater for the students away from their home country and whose parents often moved between countries as a result of their occupation. In the Introduction, the editors offer a short overview of the international

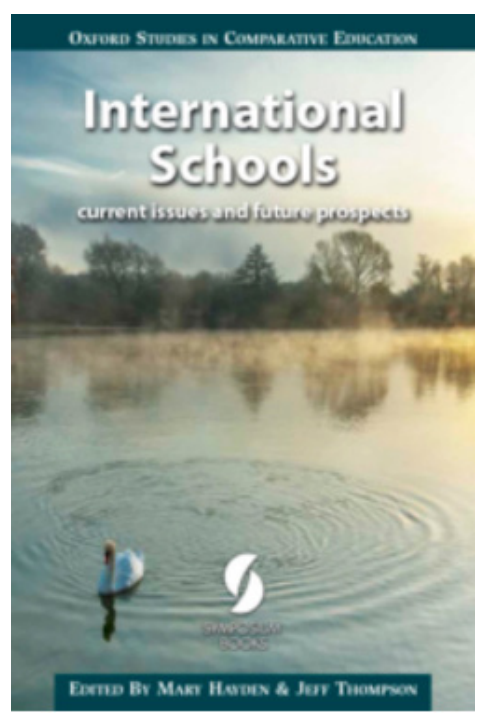
school movement and point out that with the increased professional mobility in the second half of the twentieth century, the numbers of international schools continued to grow. Around the turn of the century the international schools started accepting the host country nationals, who were attracted by the education offered in international schools for various reasons: the prestige of an international programme, the desirability of an English-medium education (as most international schools are English-medium schools), or the assumption that an international school education gives children a competitive edge over peers education in the national education system. The editors find it very difficult to propose a categorization of international schools due to the unprecedented growth in the field and the changes that are taking place at an unprecedented pace.

The book is divided into three parts: the first one is focused on the curriculum, the second deals with the organization of international schools, and

1 Gimnazija Bežigrad, International School, Slovenia; mirko.mrcela@gimb.org. 
the third discusses the current trends and future developments in the field of international education.

In the first part, Nicholas Tate identifies what he thinks the purposes of an international education are: to meet the needs of the professional expatriate communities as well as to meet the needs of local elites who have seen fluency in English and access to English-language higher education as means to advancement. Tate raises interesting questions regarding the latter and argues the international education may have quite opposing effects on national elites. He continues to address the question of where international education stands in relation to Enlightenment principles. Tate concludes by identifying three major strengths of the international education sector that the national education systems might benefit from in the future: the potential to offer consultancy and support in developing "internationally minded" curricula, greater opportunities to experiment with innovative educational approaches, and extensive experience of educating young people in places where there may be a discrepancy between the ideology of the school and parts of its surrounding environment.

George Walker, former director general of the International Baccalaureate Organization, aims to identify the features of the curricula of three international schools that pre-date the International Baccalaureate (IB): the International School of Geneva, the United Nations International School, and the United World College of the Atlantic (Atlantic College). Walker traces the history of the three schools with anecdotal insights into their struggles to establish an international curriculum, which (according to him) is characterized by a comprehensive language policy, opportunities to develop intercultural understanding and a forum for the regular discussion of global issues. All three are identified as components of what the IB terms "international mindedness". Walker believes the IB Diploma has set the "gold" standard against which other international programmes have been measured.

Tristan Stobie questions the idea of international best practice that is supposed to be a model when developing curriculum at school or national level and stresses the importance of the school's culture and context for the curriculum, as one cannot expect beneficial outcomes from a change that is not evolutionary and that shows disregard for local realities. The author believes that the new generation of international schools which are more open to indigenous students will necessarily have to show sensitivity to culture and context when implementing curricula rather than expect one model to fit all. Stobie concludes by listing some principles that might be useful in building a curriculum that considers and respects both local and global realities.

Martin Skelton's contribution focuses on learning and argues that in many schools learning is neglected because the schools have other priorities, 
e.g. performance or resources, and take learning for granted. The author acknowledges that he is writing from what he terms a "Western, liberal tradition" and claims that student learning in international schools should be driven by the questions of what kind of people the international students are hoped to become. The term "international", Skelton emphasizes, is most helpfully used in schools (regardless of the reasons that they call themselves international) that help their students become positively able to be with an other. International should be perceived as a dispositional adjective and not locational.

Judith Fabian argues that international education is best defined by the teaching strategies that are inquiry based, concept driven and contextualized. She claims that such strategies develop students as independent, lifelong learners. These ideas reflect the International Baccalaureate (IB) mission statements, and the author discusses the IB programmes to illustrate her main point: pedagogy is just as important for international education as the teaching of content is.

The second part opens with Michael Fertig's and Chris James's contribution on the leadership of international schools which the authors find to be a complex matter not least because of the rapid turnover of students and staff in many international schools, which may disrupt self-organization, connectivity, and interdependence. They see international schools as complex evolving loosely linked systems (CELLS) and use that perspective to consider their nature.

Margaret Halicioglu examines how a residential facility, where students live together with others in a respectful and supportive place, can foster intercultural understanding. She emphasizes the importance of a residential curriculum which should take into consideration all the particularities of the student composition. Halicioglu concludes that the residential setting abounds in authentic learning opportunities and underlines the need for culturally aware staff to facilitate positive intercultural interactions.

Central to Neil Richards's contribution is the idea that there is a complete lack of trust in the teaching profession, which leads to curriculum delivery becoming ever more prescriptive. Rubrics and standards, test scores and examination results, Richards claims, do not necessarily enhance learning and that issue should be addressed urgently if we do not want bureaucracy to smother creativity, initiative, and innovation. The acquisition of good test and examination results should not be the central purpose of our schools but a consequence of a good education, he claims. One way to achieve this would be by attributing to the teachers and education the importance they deserve.

The third part traces some current trends and future developments in the international education sector. It opens with Sally Booth, Malcolm McKenzie and Edward Shanahan's article in which they describe their experience of 
designing Keystone Academy in Beijing, China. The school is a blend of an American-style boarding school, international education and Chinese traditions and sensibilities and its founders offer their experience as a guide for those who are founding internationally minded schools elsewhere. The authors emphasize the importance of a school's mission statement and shared values for a new and untested school. They conclude by suggesting that any so-called world school should have a profound interest in the language, history, culture, and identity of its country or region and place it at the heart of its curriculum.

Mark Waterson explores the influence of for-profit transnational corporations, whose presence in the international school sector has been increasing in recent years, on international school education. After giving an overview of the international school market, Waterson focuses on the emergence of forprofit international schools, and invites the reader to consider what implications profitability as a driver of international school education might have. The danger he sees in this is that instead of focusing on the "internationalist" interpretations of international education, the transnational corporations may take stronger pragmatic, market-oriented positions. Waterson implies that if private international schools that serve a wealthy transnational or local elite become concentrated in the hands of for-profit global corporations, the results might not be in keeping with the original concepts of international school education.

Tristan Bunnell discusses the implications that the growth pattern in the international school sector has on international education. He also focuses on the impact the growth pattern has on the English-speaking countries, e.g. teacher shortage and concludes that growth in international schooling brings with it considerable negative externalities, many of which have not yet been explored. Bunnell invites a wider and more critical audience to the discussion of the field of international schooling and the long-term effects the growth pattern has on it.

Most authors in this book give significant attention to the unprecedented growth in the international school sector and try to add their contribution to the categorization of the field as it is characterized by a considerable diversity and constant change. With rare exceptions, they all use the International Schools Consultancy Group statistics and focus on the English-medium schools, while the discussions often remain at the level of impressive statistics and unpredictability of the impact of this growth. Since the international school field is relatively under-researched, this collection of articles offers a close examination of its history, current trends, and possible future issues. 